\title{
BIOAVAILABILITY OF CADMIUM AND LEAD IN A SOIL AMENDED WITH PHOSPHORUS FERTILIZERS
}

\author{
Alessandra Monteiro Salviano Mendes ; Gustavo Pereira Duda²; Clístenes Williams Araújo \\ do Nascimento ${ }^{3 *}$; Michelangelo Oliveira Silva ${ }^{3}$ \\ ${ }^{1}$ Embrapa Semi-árido, BR 428, km 152, C.P. 23, Zona Rural - 56302-970 - Petrolina, PE - Brasil. \\ ${ }^{2}$ Universidade Federal Rural do Semi-Árido - Depto. de Ciências Ambientais, km 47, BR 110, C.P. 137 - \\ 59625-900 - Mossoró, RN - Brasil. \\ ${ }^{3}$ UFRPE - Depto. de Agronomia - 52171-900 - Recife, PE - Brasil. \\ *Corresponding author <cwanascimento@yahoo.com>
}

\begin{abstract}
Phosphorus fertilizers are essential to obtain high productivity, however, they contain heavy metals that can contaminate the soil and threat the health of animals and humans. The present study focused the determination of $\mathrm{Cd}$ and $\mathrm{Pb}$ concentrations in different phosphorus fertilizers as well as the absorption of these heavy metals by velvet green bean grown on soil amended with such fertilizers. The experiment was set up as a completely randomized design in a factorial scheme. The factors were four phosphorus sources (triple superphosphate-TS, Yorin thermophosphate-YT, Araxa rock phosphate-AP, and Gafsa rock phosphate-GP) applied at five rates $\left(0,92,183,275\right.$, and $366 \mathrm{~kg} \mathrm{ha}^{-1}$ of $\left.\mathrm{P}_{2} \mathrm{O}_{5}\right)$. The data obtained were submitted to variance and regression analysis. Lead availability to velvet bean was not altered as a result of fertilizer application. On the other hand, Cd uptake was significantly increased with addition of the tested fertilizers. Such an increase was a function of the rate. The highest Cd contents in shoots was reached by YT and TS applications, whereas the lowest one resulted from rock phosphate treatments. All the phosphorus sources tested increased Cd uptake in the first harvest. For the second harvest, Cd content in the shoot was detected only in plants grown on TS and GP amended soils.

Key words: heavy metals, phytoextraction
\end{abstract}

\section{BIODISPONIBILIDADE DE CÁDMIO E CHUMBO EM UM SOLO ADUBADO COM DIFERENTES FONTES DE FÓSFORO}

\begin{abstract}
RESUMO: Fertilizantes fosfatados são essenciais para obtenção de altas produtividades, entretanto, eles podem conter metais pesados que podem contaminar o solo e ameaçar a saúde humana e animal. Este trabalho objetivou a determinação da concentração de Cd e Pb em diferentes fertilizantes fosfatados, bem como a absorção desses metais por plantas de mucuna preta cultivadas em casa-de-vegetação em solo submetido a diferentes doses desses fertilizantes. Os tratamentos foram arranjados em esquema fatorial 4 $\times 5$, dispostos em delineamento experimental inteiramente casualizado, com três repetições, sendo os fatores quatro fontes de $\mathrm{P}$ (superfosfato triplo-ST, termofosfato de Yorin-TY, fosfato de Araxá-FA e fosfato de Gafsa-FG) e cinco doses de $\mathrm{P}_{2} \mathrm{O}_{5}\left(0,92,183,275\right.$ e $\left.366 \mathrm{~kg} \mathrm{ha}^{-1}\right)$. Os dados foram submetidos à análise de variância e equações de regressão foram ajustadas. A disponibilidade de $\mathrm{Pb}$ para mucuna preta nos solos não foi alterada pela aplicação de nenhum dos fertilizantes testados. No entanto, a absorção de Cd pelas plantas foi significativamente aumentada pela aplicação de qualquer um dos fertilizantes, sendo esta absorção proporcional às doses aplicadas. O TY e o ST foram responsáveis pelas maiores concentrações de Cd na parte aérea das plantas, enquanto as menores foram observadas com a aplicação dos fosfatos naturais. Todas as fontes de fósforo disponibilizaram Cd para as plantas no primeiro cultivo. Entretanto, a absorção de Cd só foi detectada no segundo cultivo para os fertilizantes ST e FG.

Palavras-chave: metais pesados, fitoextração
\end{abstract}

\section{INTRODUCTION}

Soil contamination by heavy metals originating from phosphate fertilizers has become a concern in several countries. Thus, much research has been conducted to evaluate the presence of such metals in these amendments (Gabe \& Rodella, 1999; Camargo et al.,
2000; Prochnow et al., 2001; McBride \& Spiers, 2001; Loganathan et al., 2003; Alves, 2003). The heavy metal concentration in phosphate fertilizers is dependent on the type of rock phosphate used as raw material. The main Brazilian rock phosphates are low in heavy metals (Langenbach \& Sarpa, 1985; Camargo et al., 2000). For this reason, soluble phosphorus fertilizers produced 
from such sources presented Cd concentrations ranging from 5.1 to $9.4 \mathrm{mg} \mathrm{kg}^{-1}$ (Prochnow et al., 2001). Low concentrations of $\mathrm{Pb}$, which varied from 5.7 to $9.9 \mathrm{mg} \mathrm{kg}^{-1}$, were also found in superphosphates (McBride \& Spiers, 2001).

Due to the relatively low concentrations of Cd and $\mathrm{Pb}$ in fertilizers, many researchers (Langenbach \& Sarpa, 1985; Camargo et al., 2000; Prochnow et al., 2001) have recommended their use without drawbacks regarding environmental contamination. However, little information is available either on the uptake of heavy metals by plants in soils fertilized with different phosphate fertilizers or on the long term accumulation of such metals in soils. Cadmium concentration in maize amended with phosphate fertilizers was significantly affected not only by P sources but also by their localization in the soil (Prochnow et al., 2001). The application of fertilizers could increase the heavy metal bioavailability in soils due to the chemical alterations they provoked in the system (Tu et al., 2002).

Taking into account that phosphate fertilizers can be an important via of heavy metals to the food chain, this work aimed to determine the $\mathrm{Cd}$ and $\mathrm{Pb}$ concentration in different phosphate fertilizers, as well as the uptake of these heavy metals by velvet beans ( $M u$ cuna aterrima L.) grown on soil amended with them. Velvet bean is a legume usually utilized as green manure due to its nitrogen fixing ability. It presents high Ca demand and a capacity to acidify the rhizosphere. These characteristics make it efficient in the use of soil $P$ (Novais \& Smith, 1999) and, therefore, in the solubilization of metals present in phosphate fertilizers.

\section{MATERIAL AND METHODS}

The soil used in the experiment was a loamy Ultisol (Argissolo Vermelho Amarelo according to the Brazilian classification) collected from the $0-20 \mathrm{~cm}$ depth in Mossoró, Rio Grande do Norte State, Brazil (0509'59,55' Se; 37²4'39,92'' W), air dried, crushed and sieved through a $2 \mathrm{~mm}$ sieve. The soil was chemically characterized according to the methods described in EMBRAPA (1997) (Table 1). The $\mathrm{Cd}$ and $\mathrm{Pb}$ total concentrations in the phosphate fertilizers were obtained by nitric-perchloric acid digestion $(3: 1 \mathrm{v} / \mathrm{v})$ (Table 2).

Soil samples of $3 \mathrm{dm}^{3}$ placed in plastic pots received different rates of four sources of P: triple su- perphosphate (TS), Araxa rock phosphate (AP), Yorin thermophosphate (YT), and Gafsa rock phosphate (GP). The P (equivalent to rates of $0,92,183,275$, and $366 \mathrm{~kg} \mathrm{ha}^{-1}$ of $\mathrm{P}_{2} \mathrm{O}_{5}$ ) was incorporated into each soil sample in the pots. Five seeds of velvet beans, submitted to mechanical scarification for dormancy break, were used in each pot. After germination, only one plant per pot was left.

Aiming to evaluate the effect of the time of contact between soil and fertilizer on $\mathrm{Cd}$ and $\mathrm{Pb}$ uptake, two 51-day successive croppings with velvet beans were carried out. At the end of each cropping, shoots were cut and dried in a forced-air oven at $65^{\circ} \mathrm{C}$ for 48 hours to obtain dry matter. These samples were crushed in a mill and digested with nitric-perchloric acid mixture (EMBRAPA, 1997). Cadmium and $\mathrm{Pb}$ were analyzed by flame atomic absorption spectrophotometry.

The treatments were arranged in a $4 \times 5$ factorial scheme, set in a completely randomized block design, with three replications. Data were submitted to variance analysis and regression equations adjusted at $1 \%$ of probability.

\section{RESULTS AND DISCUSSION}

The rock phosphates presented different heavy metal concentrations (Table 2). Cadmium and $\mathrm{Pb}$ concentrations in the Araxa rock phosphate lie in the normal metal concentration range found in the literature for rock phosphates (Kpomblekou \& Tabatabai, 1994; Alves, 2003). The concentration of $\mathrm{Cd}$ and $\mathrm{Pb}$ were at least three times lower in the Araxa phosphate in relation to the Gafsa rock phosphate. This result agrees with other statements that Brazilian rock phosphates present low heavy metal concentrations (Langenbach \& Sarpa, 1985; Camargo et al., 2000) and that such concentrations vary for phosphates obtained from different regions. Cadmium and $\mathrm{Pb}$ concentrations in triple superphosphate are above the concentrations obtained in other studies (Prochnow et al., 2001; McBride \& Spiers, 2001). The Yorin thermophosphate presented the lowest $\mathrm{Cd}$ concentration. On the other hand, Yorin $\mathrm{Pb}$ concentration was only smaller than that of the Gafsa rock phosphate.

For all fertilizers, $\mathrm{Pb}$ was higher than $\mathrm{Cd}$ (Table 2). However, in spite of the relatively high concentration of $\mathrm{Pb}$ in the fertilizers, this element was not

Table 1 - Chemical characteristics of the soil.

\begin{tabular}{|c|c|c|c|c|c|c|c|c|c|c|}
\hline $\mathrm{pH}$ & $\mathrm{P}$ & $\mathrm{OM}$ & $\mathrm{K}^{+}$ & $\mathrm{Ca}^{+2}$ & $\mathrm{Mg}^{+2}$ & $\mathrm{H}^{+}+\mathrm{Al}^{+3}$ & CTC & Clay & Silt & Sand \\
\hline & $\mathrm{mg} \mathrm{dm}{ }^{-3}$ & $\mathrm{~g} \mathrm{~kg}^{-1}$ & - & -1 & $\mathrm{~mol}_{\mathrm{c}} \mathrm{d}$ & - & - - - & -....- & $\mathrm{g} \mathrm{kg}^{-}$ & - \\
\hline 7.7 & 2.0 & 2.0 & 0.2 & 2.5 & 0.6 & 1.8 & 5.1 & 100 & 20 & 880 \\
\hline
\end{tabular}


detected in the shoots of the velvet bean plants in both croppings. This result is probably due to the low $\mathrm{Pb}$ translocation in plants and its preferential accumulation in roots (Alloway, 1990). However, the low availability of this metal in alkaline soils as the one used in this work, along with the low solubility of Pb phosphates (Sparks, 2003), seems also to be a decisive factor. It should also be pointed out that the application of agronomic rates of the phosphates fertilizers would not increase the $\mathrm{Pb}$ concentration above the levels naturally found in soils. One thousand hundred and thirty applications of the highest rate of the Gafsa phosphate would be necessary to increase the soil concentration at the intervention level for $\mathrm{Pb}$ in agricultural soils (200 $\mathrm{mg} \mathrm{kg}^{-1}$ ) proposed by CETESB (2001). This makes the

Table 2 - Pb and Cd contents in the phosphate fertilizers used and metals quantities incorporated by the highest rate.

\begin{tabular}{lcc}
\hline Fertilizers & $\mathrm{Pb}$ & $\mathrm{Cd}$ \\
\hline & $-\ldots-\cdots-\mathrm{mg} \mathrm{kg}^{-1}$ & $-\ldots-\cdots$ \\
Gafsa rock phosphate & $238(355.4)$ & $61(91.1)$ \\
Triple Superphosphate & $45(45.9)$ & $28(28.5)$ \\
Yorin Thermophosphate & $110(256.3)$ & $11(25.6)$ \\
Araxa rock phosphate & $51(55.7)$ & $15(16.4)$ \\
\hline
\end{tabular}

Numbers in parenthesis refer to $\mathrm{g} \mathrm{ha}^{-1}$.
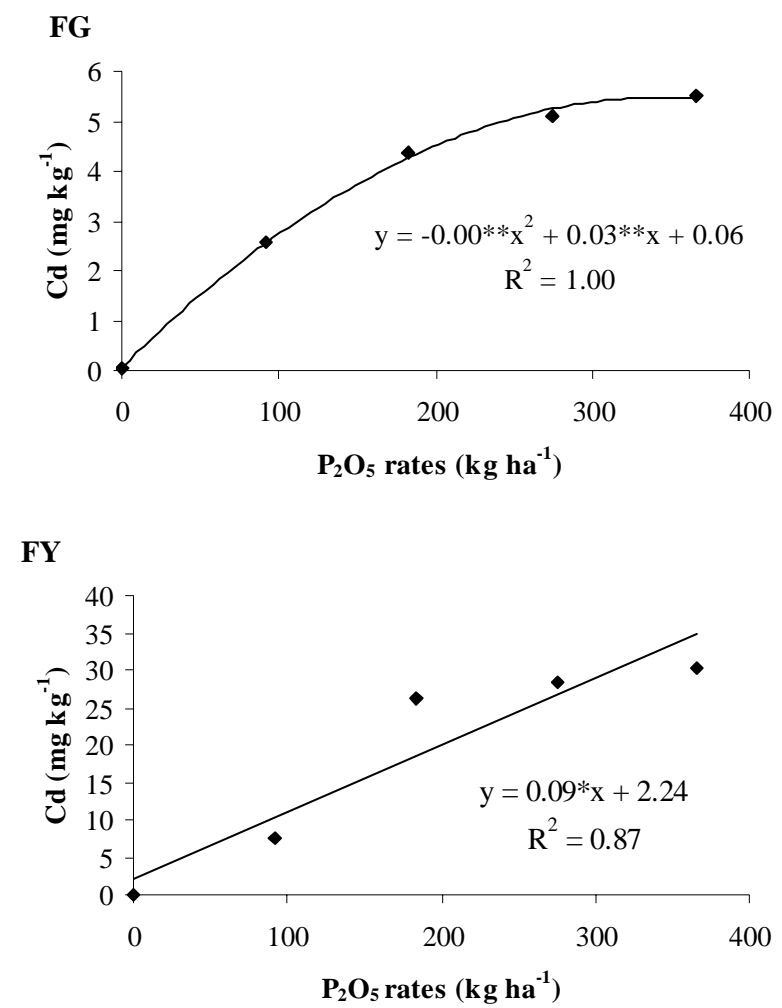

use of these phosphorus fertilizers very safe regarding $\mathrm{Pb}$. It should be emphasized, however, that monitoring $\mathrm{Pb}$ uptake by plants in soils must be evaluated the in the long term, since $\mathrm{Pb}$ availability can increase due to chemical alterations in the soil, particularly lowering the $\mathrm{pH}$.

In contrast with the observations on $\mathrm{Pb}$, there was a significant effect of the sources and $\mathrm{P}$ rates, as well as the interaction among these factors, on the Cd concentrations in the shoots of velvet bean (Figures 1 and 2). There was no clear relation between $\mathrm{Cd}$ concentrations in fertilizers and the concentration of this element in the first harvest. This can be attributed to the solubility of the different sources. The lowest Cd concentrations were observed in plants fertilized with natural phosphates, especially Araxa rock phosphate, whilst triple superphosphate and Yorin thermophosphate supplied the largest amounts of $\mathrm{Cd}$ available. The $\mathrm{Ca}$ and $\mathrm{P}$ concentrations in plants were also higher for Yorin and triple superphosphate than for rock phosphates (data not shown). This corroborates to the effect of source solubility on Cd uptake. The Yorin thermophosphate presented the lowest Cd concentration among the tested fertilizers and supplied only the third largest amount of the element to the soil (Table 2). Nevertheless, this fertilizer provided the largest Cd concentration in the plants in all the tested rates
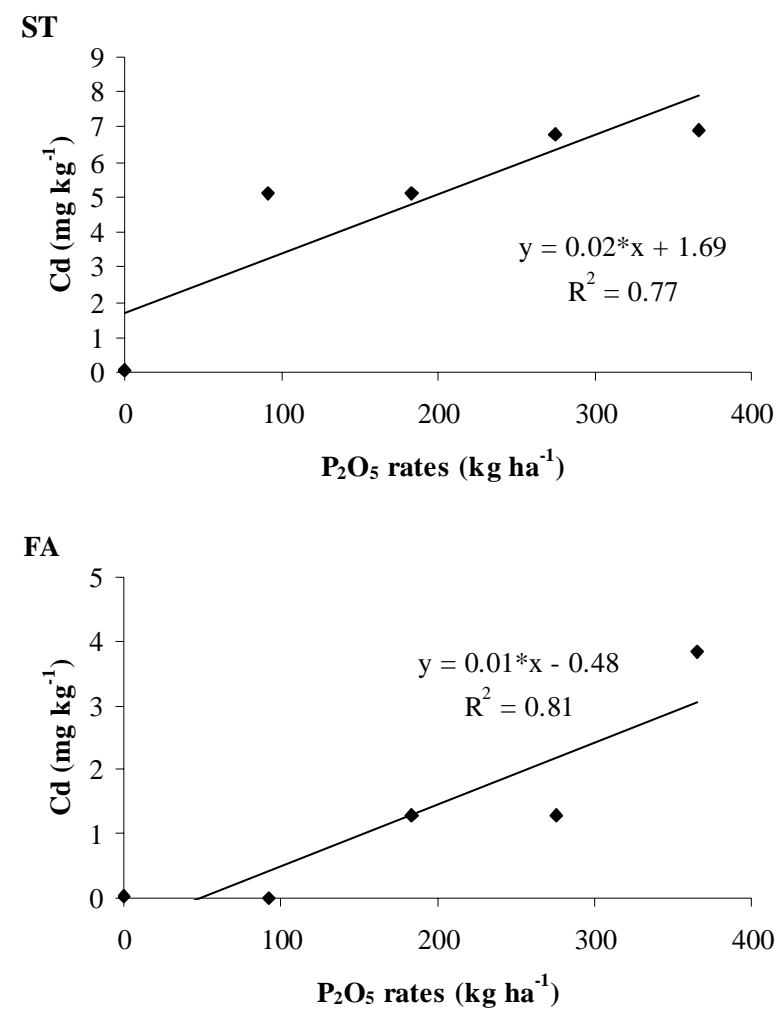

Figure 1 - Cd concentrations in shoots of velvet beans (first harvest) as a function of phosphorus fertilizer rates (GP- Gafsa rock phosphate; TS- Triple Superphosphate; YT- Yorin thermophosphate; AP- Araxá rock phosphate). 
(Figure 1). This indicates that the Cd chemical form in this fertilizer was propably decisive in determining the Cd solubility and plant uptake.

Other authors also found increases in Cd uptake by plants as a consequence of phosphate fertilizer applications (Mulla et al., 1980; Mortvedt, 1987; Silva, 1994; Gonçalves Jr. et al., 2000; Prochnow et al., 2001). Therefore, these results indicate that phosphate fertilizers can be an important via for Cd entry in the food chain. However, more than 220 applications of Gafsa rock phosphate (fertilizer with the highest Cd concentration) would be necessary to increase $\mathrm{Cd}$ in the soil to $10 \mathrm{mg} \mathrm{kg}^{-1}$, the figure suggested as the intervention value by CETESB (2001). The Cd translocation to the aboveground parts of the plants observed in here suggests that more studies are needed, owing to concerns regarding $\mathrm{Cd}$ accumulation at the highest levels of the food chain.

For the second harvest, only triple superphosphate and Gafsa rock phosphate provided available $\mathrm{Cd}$ for the plants. In this case, Cd concentration in plants grown on soil samples fertilized with triple superphosphate was significantly higher (Figure 2). The residual effect on Cd uptake for the plants treated with Gafsa rock phosphate was due to Gafsa's lower solubility and higher Cd content as compared to triple superphosphate. In spite of the high solubility of the triple superphosphate, the Cd concentration in plants grown on soil amended with this fertilizer was higher in the second harvest as compared to the first. This can be due to the low adsorption of $\mathrm{Cd}$ on specific adsorption sites

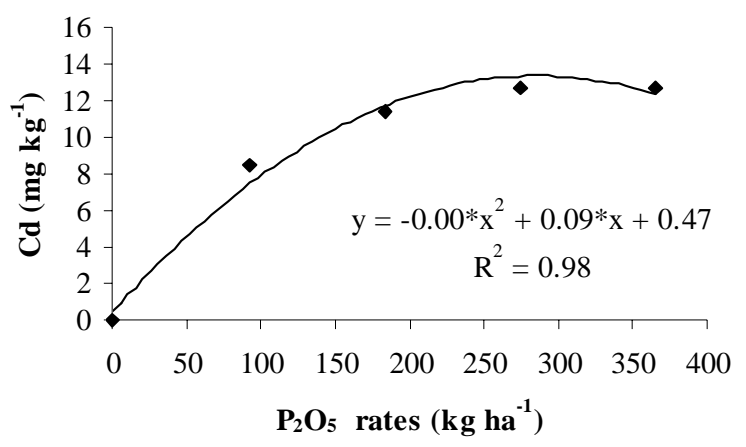

Figure 2 - Cd concentrations in shoots of velvet beans (second harvest) as a function of triple superphosphate rates. in the soil (Alloway, 1990) and to the low cation exchange capacity of the soil. These facts probably made possible the maintenance of soluble Cd for a more extended time, although one should have in mind that the pots used in this study were not open-ended. In field conditions, such high Cd solubility could induce leaching through the soil profile.

Based on equations, the rates of both Gafsa rock phosphate in the first harvest and triple superphosphate in the second harvest that would lead to the maximum Cd concentration in the aboveground part of the velvet beans were obtained. In addition, the efficiency of these fertilizers in making $\mathrm{Cd}$ available to plants was also calculated (Table 3).

Triple superphosphate was more efficient at supplying $\mathrm{Cd}$ in the second cropping $\left(0.047 \mathrm{mg} \mathrm{kg}^{-1}\right.$ of $\mathrm{Cd}$ for each $\mathrm{kg}$ of $\mathrm{P}_{2} \mathrm{O}_{5}$ applied) when compared to the first one $\left(0.023 \mathrm{mg} \mathrm{kg}^{-1}\right.$ of $\mathrm{Cd}$ for each $\mathrm{kg}$ of $\mathrm{P}_{2} \mathrm{O}_{5}$ applied). Gafsa rock phosphate, on the other hand, provided a maximum Cd concentration in the first harvest lower than triple superphosphate. Gafsa phosphate also presented the lowest efficiency for Cd supply (0.015 $\mathrm{mg} \mathrm{kg}{ }^{-1}$ of $\mathrm{Cd}$ for each $\mathrm{kg}$ of $\mathrm{P}_{2} \mathrm{O}_{5}$ applied). The low solubility of Gafsa rock phosphate as compared to triple superphosphate is the most probable reason for such result.

\section{REFERENCES}

ALLOWAY, B.J. Heavy metals in soils. 1.ed. New Jersey: John Wiley \& Sons, 1990. 339p.

ALVES, R.N. Avaliação de um fosfato natural e termofosfatos quanto aos teores totais de metais pesados e à disponibilidade de micronutrientes. Viçosa: UFV, 2003. 35p. (Dissertation - M.Sc.).

CAMARGO, M.S.; ANJOS, A.R.M. dos; ROSSI, C.; MALAVOLTA, E. Adubação fosfatada e metais pesados em Latossolo cultivado com arroz. Scientia Agricola, v.57, p.513-518, 2000.

COMPANHIA DE TECNOLOGIA DE SANEAMENTO AMBIENTAL DO ESTADO DE SÃO PAULO - CETESB. Relatório de estabelecimento de valores orientadores para solos e águas subterrâneas no estado de São Paulo. São Paulo: CETESB, 2001. 232p.

EMPRESA BRASILEIRA DE PESQUISA AGROPECUÁRIA EMBRAPA. Manual de métodos de análises de solo. Brasília: EMBRAPA, Comunicação para Transferência de Tecnologia, 1997. 212p.

GABE, U.; RODELLA, A. Trace elements in Brazilian agricultural limestones and mineral fertilizers. Communications in Soil Science and Plant Analysis, v.30, p.605-620, 1999.

Table $3-\mathrm{P}_{2} \mathrm{O}_{5}$ doses for maximum Cd concentration in the shoots of velvet beans and the Cd supply efficiency for each phosphate fertilizer.

\begin{tabular}{lccc}
\hline Fertilizers & $\mathrm{P}_{2} \mathrm{O}_{5}$ rates & $\mathrm{Cd}$ content in plant & Efficiency $^{1}$ \\
\hline Gafsa rock phosphate & $\mathrm{kg} \mathrm{ha}^{-1}$ & $\mathrm{mg} \mathrm{kg}^{-1}$ & \\
Triple Superphosphate $-2^{\text {nd }}$ harvest & 313.00 & 5.0 & 0.016 \\
\hline
\end{tabular}

${ }^{1}$ Cadmium concentration in shoots $/ \mathrm{kg} \mathrm{P}_{2} \mathrm{O}_{5}$ applied 
GONÇALVES JR., A.C.; LUCHESE, E.B.; LENZI, E. Avaliação da fitodisponibilidade de cádmio, chumbo e crômio, em soja cultivada em Latossolo Vermelho escuro tratado com fertilizantes comerciais. Química Nova, v.23, p.173-177, 2000.

KPOMBLEKOU, K.; TABATABAI, M.A. Metal contents of phosphate rocks. Communications in Soil Science and Plant Analisys, v.25, p.2871-2882, 1994.

LANGENBACH, T.; SARPA, M. Teor de cádmio nos fertilizantes fosfatados brasileiros. Revista Brasileira de Ciência do Solo, v.9, p.179-181, 1985.

LOGANATHAN, P.; HEDLEY, M.J.; GRACE, N.D.; LEE, J.; CRONIN, S.J.; BOLAN, N.S.; ZANDERS, J.M. Fertiliser contaminants in New Zealand grazed pasture with special reference to cadmium and fluorine - a review. Australian Journal of Soil Research, v.41, p.501-532, 2003.

MCBRIDE, M.B.; SPIERS, G. Trace element content of selected fertilizers and dairy manures as determined by ICP-MS. Communications in Soil Science and Plant Analisys, v.32, p.139156, 2001.

MORTVEDT, J.J. Cadmium levels in soils and plants from some long term soil fertility experiments in the United States of America. Journal of Environmental Quality, v.16, p.137-142, 1987.
MULLA, D.J.; PAGE, A.L.; GANJE, T.J. Cadmium accumulations and bioavailability in soil from long term phosphorus fertilization. Journal of Environmental Quality, v.9, p.408-412, 1980.

NOVAIS, R.F.; SMYTH, T.J. Fósforo em solo e planta em condições tropicais. Viçosa: DPS/UFV, 1999. 399p.

PROCHNOW, L.I.; PLESE, L.M.; ABREU, M.F. Bioavailability of cadmium contained in single superphosphates produced from different Brazilian raw materials. Communications in Soil Science and Plant Analysis, v.32, p.283-294, 2001.

SILVA, A.J. Metais pesados em plantas de milho (Zea maysL.) cultivadas com diferentes fontes e doses de fósforo, formas de localização de fertilizantes e níveis de calagem. Viçosa: UFV, 1994. 135p. (Thesis - Ph.D.).

SPARKS, D.L. Environmental soil chemistry. 2.ed. San Diego: Academic Press, 2003. 352p.

TU, C.; ZHENG, C.R.; CHEN, H.M. Effect of applying chemical fertilizers on forms of lead and cadmium in red soil. Chemosphere, v.41, p.133-138, 2002.

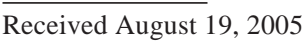

Accepted June 14, 2006 